\title{
25. DATA REPORT: CHEMISTRY OF PORE FLUIDS IN SEDIMENTS OF HOLE 893B, SANTA BARBARA BASIN ${ }^{1}$
}

\author{
Miriam Kastner ${ }^{2}$
}

\section{MINERALS AND METHODS}

Hole 893B was drilled in the central Santa Barbara Basin, a few hours before port call. Therefore, these Ocean Drilling Program Leg 146 pore fluids, which were obtained by routine shipboard squeezing of whole-round sediment samples immediately after retrieval, were analyzed aboard the ship only for alkalinity. The remaining pore fluids were sealed and analyzed in the shore-based laboratories of Scripps Institution of Oceanography. The shipboard procedures involved squeezing the sediments in titanium squeezers at ambient temperature and at pressures of 135-205 MPa (140-210 kg/cm²).

The methods used for the chemical analyses are described in Gieskes et al. (1991). Table 1 is a summary of the pore fluid chemical data from Hole 893B. Only four pore fluid samples were obtained. Except for Sample 146-893B-5H-5, 140-150 cm, from a bioturbated sediment section, the other three samples are from laminated sediment sections.

\section{SUMMARY OF RESULTS}

Despite the very high methane concentrations of about 80,000 ppmv already at $\sim 10$ meters below seafloor (mbsf) (pers. comm., Shipboard Organic Geochemists, 1992), sulfate reduction is incomplete in the uppermost $\leq 20 \mathrm{~m}$ drilled, suggesting either intensive irrigation in the suboxic to oxic bottom-water environment or, more likely, advection of methane from greater depths into the sulfate reduction zone where pyrite forms. The high alkalinities reflect the intensity of organic matter remineralization and the high sedimentation rates, effecting carbonate diagenesis. The significantly lower-thanseawater calcium concentrations even at 1.5 mbsf indicate that a $\mathrm{Ca}$ rich mineral is precipitating. Calcium may be consumed by francolite (carbonate-F-apatite) precipitation; however, the high alkalinity con- centrations would destabilize francolite, favoring carbonate formation (Kastner et al., 1984). On the basis of the high $\mathrm{Mg} / \mathrm{Ca}$ ratios of 2 to almost 4 times the seawater ratio, the very high alkalinity and low sulfate concentrations, in addition to calcite, $\mathrm{Mg}$ calcite, and/or dolomite, are most likely actively forming in these sediments (Baker and Kastner, 1981; Kastner et al., 1984). Active carbonate precipitation is also supported by the lower-than-seawater strontium concentrations. The higher-than-seawater potassium and sodium concentrations strongly suggest that both have been expelled from clay exchange sites, most likely by ammonia, a by-product of organic matter remineralization. Silica concentrations are high; already at the shallowest sample, at $1.5 \mathrm{mbsf}$, the pore fluid is almost saturated with respect to opal-A. It reaches saturation at $\sim 55 \mathrm{mbsf}$. The origin of the rather low silica concentration at 20.8 mbsf (Sample 146-893B-3H-6, 140$150 \mathrm{~cm}$ ) of $336 \mathrm{mM}$ is unclear. A sandy horizon at this depth may be responsible for it.

\section{REFERENCES}

Baker, P.A., and Kastner, M., 1981. Constraints on the formation of sedimentary dolomite. Science, 213:215-216.

Gieskes, J.M., Gamo, T., and Brumsack, H., 1991. Chemical methods for interstitial water analysis aboard JOIDES Resolution. ODP Tech. Note, 15.

Kastner, M., Mertz, K.A., Hollander, D., and Garrison, R.E., 1984. The association of dolomite-phosphorite-chert: causes and possible diagenetic sequences. In Garrison, R.E., Kastner, M., and Zenger, D.H. (Eds.), Dolomites of the Monterey Formation and Other Organic-rich Units. Soc. Econ. Paleontol. Mineral, Fieldtrip Guidebook., Pacific Sect., $41: 75-86$

Date of initial receipt: 19 August 1994

Date of acceptance: 9 November 1994

Ms 146SR-308

Table 1. Chemistry of interstitial water samples from Hole 893B.

\begin{tabular}{|c|c|c|c|c|c|c|c|c|c|c|c|c|c|c|c|}
\hline $\begin{array}{l}\text { Core. section. } \\
\text { interval }(\mathrm{cm})\end{array}$ & $\begin{array}{l}\text { Depth } \\
\text { (mbsf) }\end{array}$ & $\mathrm{pH}$ & $\begin{array}{l}\text { Alkalinity } \\
\text { (mM) }\end{array}$ & $\begin{array}{l}\text { Salinity } \\
(\mathrm{g} / \mathrm{kg})\end{array}$ & $\underset{(\mathrm{mM})}{\mathrm{Cl}}$ & $\underset{(\mathrm{mM})}{\mathrm{Mg}}$ & $\underset{(\mathrm{mM})}{\mathrm{Ca}}$ & $\mathrm{Mg} / \mathrm{Ca}$ & $\begin{array}{c}\mathrm{SO}_{4} \\
(\mathrm{mM})\end{array}$ & $\begin{array}{l}\mathrm{SiO}_{2} \\
(\mu \mathrm{M})\end{array}$ & $\underset{(\mathrm{mM})}{\mathrm{K}}$ & $\begin{array}{c}\mathrm{Na} \\
(\mathrm{mM})\end{array}$ & $\mathrm{Na} / \mathrm{Cl}$ & $\underset{(\mu \mathrm{M})}{\mathrm{Li}}$ & $\begin{array}{c}\mathrm{Sr} \\
(\mu \mathrm{M})\end{array}$ \\
\hline \multicolumn{16}{|l|}{ 146-893B- } \\
\hline $\mathrm{IH}-1.140-150$ & 1.5 & 7.9 & 42.63 & 33.5 & 557 & 49.13 & 4.49 & 10.9 & 3.6 & 917 & 12.09 & 488 & 0.88 & 17.1 & 73.1 \\
\hline $3 \mathrm{H}-6,140-150$ & 20.8 & 7.6 & 57.21 & 34.5 & 561 & 51.03 & 2.56 & 19.9 & 0.6 & 336 & 13.04 & 499 & 0.89 & 17.7 & 59.0 \\
\hline $5 \mathrm{H}-5,140-150$ & 38.3 & 7.7 & 43.64 & 33.5 & 563 & 42.62 & 2.18 & 19.6 & 0.7 & 944 & 13.79 & 505 & 0.90 & 30.5 & 56.7 \\
\hline $7 \mathrm{H}-6,106-116$ & 58.4 & 7.7 & 44.99 & 33.5 & 557 & 39.85 & 2.13 & 18.7 & 0.8 & 1081 & 13.99 & 506 & 0.91 & 28.2 & 59.0 \\
\hline
\end{tabular}

'Kennett. J.P., Baldauf, J.G., and Lyle. M. (Eds.). 1995. Proc. ODP. Sci. Results.

146 (Pt. 2): College Station. TX (Ocean Drilling Program).

'Scripps Institution of Oceanography, La Jolla, CA 92093, U.S.A. 